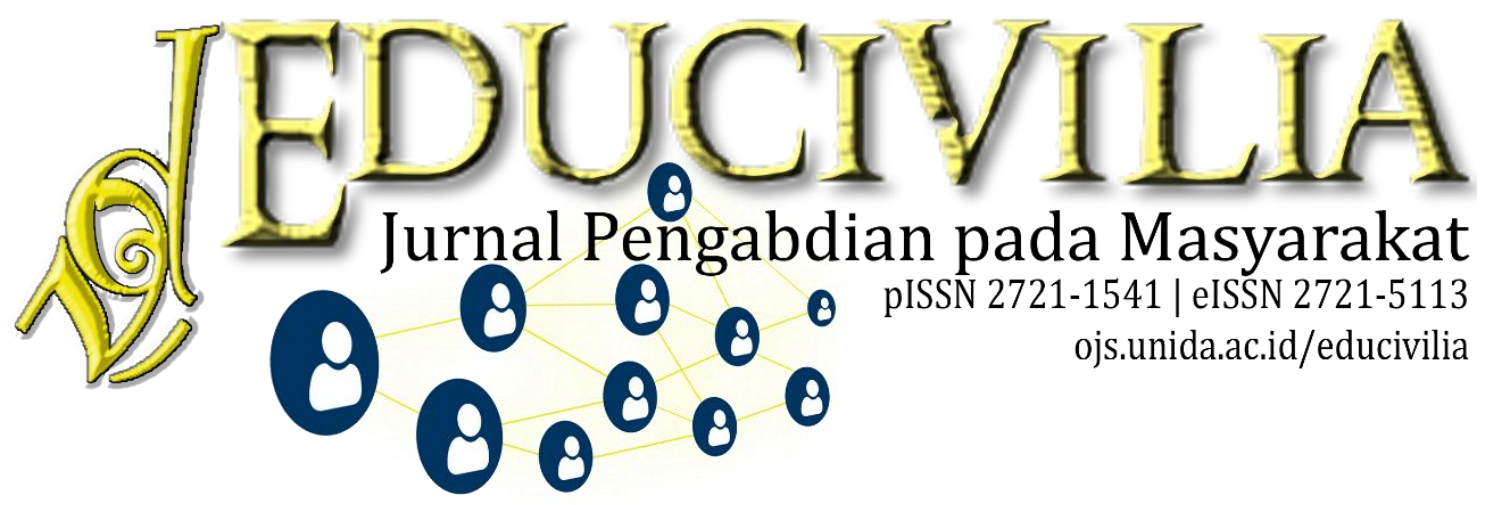

\title{
Pelatihan Mengelas Bagi Karang Taruna dan Remaja Putus Sekolah Di Kecamatan Cileungsi
}

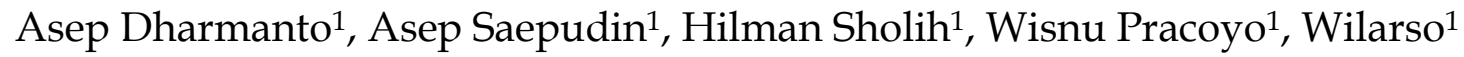 \\ ${ }^{1}$ Program Studi Teknik Mesin, Sekolah Tinggi Teknologi Muhammadiyah Cileungsi, Jl. Anggrek, \\ No 25, Perum PTSC, Cileungsi, Bogor, Jawa Barat, Indonesia, 16820
}

Kilas Artikel

Volume 1 Nomor 2

Juli 2020: 131-142

DOI: $10.30997 /$ ejpm.v1i2.2889

Article History

Submission: 24-06-2020

Revised: 08-07-2020

Accepted: 16-07-2020

Published: 22-07-2020

Kata Kunci:

Hard Skill, Pelatihan

pengelasan, Pendidikan Non

Formal, Soft Skill,

Keywords:

Hard Skill, Non Formal

Education, Soft Skill Welding

training.

Korespondensi:

Wilarso

wilarso@sttmcileungsi.ac.id

\begin{abstract}
Abstrak
Peningkatan Sumber Daya Manusia harus terus ditingkatkan terutama di bidang pendidikan non formal. Peningkatan keahlian di dunia industri cenderung perkembangannya cukup pesat, jika SDM tidak dibekali dengan kemampuan soft skill dan hard skill akan menurunkan kemampuan bersaing di industri. Ini yang akan menjadi beban mereka, yang tentunya sangat dibutuhkan oleh pemuda-pemuda dengan kemauan berkembang untuk meningkatkan hard skill dan soft skill. Diadakan pelatihan ini, salah satu program Sekolah Tinggi Teknologi Muhammadiyah Cileungsi yang bertujuan meningkatkan kualitas pemudapemuda yang ada di lingkungan Sekolah Tinggi Teknik Muhammadiyah Cileungsi dan sekitarnya. Sedangkan di dalam lingkungan industri meningkatkan SDM untuk bersaing dalam kualitas pengelasan dan meningkatkan kualitas produk, serta menjalin hubungan baik antara perguruan tinggi dan masyarakat sekitar industri. Pelatihan pengelasan yang sangat dibutuhkan, wirausaha, industri maupun di proyek. Bidang hard skill melalui adanya pelatihan ini, dapat membantu kesulitankesulitan pemuda-pemuda di wilayah Cileungsi dalam dunia industri dan upaya untuk menambah kemampuan bidang keterampilan pengelasan dengan kerjasama antara STTMC dengan PT. CG Power Indonesia. Serta akhir sesi pelatihan diberikan 1 perlengkapan alat las untuk pemuda karang taruna yang mengikuti pelatihan, untuk daerahnya masing-masing.

\begin{tabular}{l} 
Introducing Welding Entrepreneurship for Youth and Youth \\
Drop Out of School in Cileungsi District \\
Abstract \\
\hline Increasing Human Resources must continue to be improved, especially \\
in the field of non-formal education. Increased expertise in the indus- \\
trial world tends to be quite rapid development if human resources are \\
not equipped with soft skills and hard skills will reduce the ability to \\
compete in the industry. This will be their burden, which is certainly \\
needed by young people with a growing willingness to improve hard \\
skills and soft skills. The training was held, one of the Sekolah Tinggi \\
Teknologi Muhammadiyah Cileungsi (STTMC) which aims to im- \\
prove the quality of young people in the STTMC and its surroundings.
\end{tabular}
\end{abstract}




Whereas in the industrial environment increasing human resources to
compete in welding quality and improving product quality, as well as
establishing good relations between universities and the community
around the industry. Welding training that is needed, entre-
preneurship, industry, or project. The field of hard skills through this
training can help the difficulties of young people in the area of
Cileungsi in the industrial world and efforts to increase the ability of
the field of welding skills with the collaboration between STTMC and
PT. CG Power Indonesia. And at the end of the training session was
given 1 welding equipment for youths who took part in the training,
for their respective regions.

\section{PENDAHULUAN}

Saat ini kualitas sumber daya manusia harus ditingkatkan, terutama di bidang pendidikan non formal (Id, Type, \& Education, 2008). Setiap individu harus mampu meningkatkan skill di dunia kerja agar bisa bersaing dengan SDM luar negeri dan setiap individu harus memiliki hard skill maupun soft skill (Vishnu \& Tunuguntla, 2017).

Berbagai pekerjaan yang dilakukan di bidang industri, otomotif, pesawat terbang, perkapalan, tambang, onshore atau offshore sering menggunakan alat las berbagai tipe dan kapasitas (Michie \& Sheehan, 2005).

Peran serta dunia industri untuk mengembangkan dunia pendidikan di butuhkan sekali, agar dunia pendidikan menjadi ruang dalam mengelola sumber daya manusia yang berkualitas (Michie \& Sheehan, 2005). Bukti dalam kepedulian aktifitas di pendidikan dari PT. CG Power Systems Indonesia, yang diwakili dari beberapa perwakilan berkunjung ke STTMC untuk memberikan bantuan hibah berupa peralatan mesin las beserta perlengkapannya. Hibah tersebut akan dipergunakan untuk pengabdian kepada masyarakat yang diadakan oleh STTMC. Pada gambar 1 kunjungan dari PT. CG Power Systems Indonesia dalam serah terima peralatan pengelasan.

Untuk memenuhi kebutuhan primer maupun sekunder masyarakat dituntut untuk bekerja, dalam pelaksanaan tersebut kemampuan dalam melakukan pekerjaan selalu terkendala pada pendidikan dan skill pekerjaan (Weber, Crawford, \& Dennison, 2012). Jika pendidikan menjadi suatu kendala dalam melaksanakan pekerjaan maka SDM tersebut harus menempuh pendidikan formal dan non formal (Id et al., 2008).

Pelatihan hard skill ini untuk menunjang peningkatan kemampuan SDM (Michie \& Sheehan, 2005) di bidang pengelasan. Pengabdian kepada masyara- 
kat ini bagian dari Catur Dharma Perguruan Tinggi untuk mengabdi kepada masyarakat agar bisa memberikan pembelajaran dan meningkatkan taraf hidup masyarakat sekitar Sekolah Tinggi Teknologi Muhammadiyah Cileungsi.

Perwakilan dari PT. CG (Bapak Ardie) menyerahkan secara simbolis peralatan pengelasan ke Ketua STTMC (Bapak Ir. Firmansyah Azharul, MT) di Sekolah Tinggi Teknologi Muhammadiyah Cileungsi.

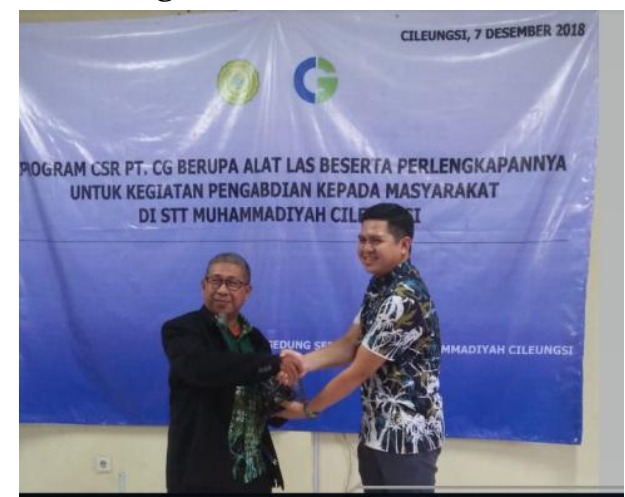

Gambar 1. Serah terima mesin las dari PT. CG ke Ketua STTMC

Dalam hal pengelasan selaku operator las harus mempunyai sertifikasi sebagai operator las, sebelum mempunyai sertifikasi las, maka wajib mengikuti pelatihan pengelasan (Architecture, Operations, \& Operations, 2011).

Pekerjaan pengelasan yang berkaitan dengan paparan panas, pancaran busur nyala, dan polusi udara serta gas, baik yang berasal dari terbakarnya coating maupun gas lindung (Golbabaei \& Khadem, 2015), dan jika terkena ja- ringan tubuh atau terhisap dalam jangka waktu yang lama akan menyebabkan gangguan kesehatan yang cukup serius dan dapat meninggalkan cacat permanen atau bahkan kematian. Selanjutnya pekerjaan las juga menyebabkan timbulnya risiko terjadinya bahaya kebakaran atau peledakan. Dari hal-hal tersebut diatas, perlu diberikan pengetahuan tentang tindakan pencegahan terhadap terjadinya bahaya kebakaran maupun gangguan kesehatan yang sistematis dan sesuai dengan kaidah internasional maupun peraturan yang berlaku (European, 2013).

Bertolak dari paparan latar belakang diatas maka institusi pendidikan dan industri harus berjalan bersamaan untuk bertanggung jawab terhadap pentingnya pendidikan dan pembangunan daerah untuk menyelenggarakan pengabdian kepada masyarakat terhadap pendidikan non formal dalam Meningkatkan Kemampuan dan Keterampilan Di bidang Pengelasan (Lankoti \& Tech, 2019).

Tujuan dari pengabdian kepada masyarakat ini adalah untuk memberikan pelatihan keterampilan pengelasan, memberikan kepercayan diri dengan keterampilan mengelas bisa membuka 
kreativitas wirausaha bagi pemuda karang taruna dan remaja putus sekolah di sekitar kampus di Kecamatan Cileungsi, serta untuk mengembang skill individu agar meningkatkan kesejahteraan pada masyarakat (Windusari \& Magelang, n.d.). Dan bagi dosen dapat mengembangkan materi perkuliahan dalam bidang akademisi serta meningkatkan kemampuan dosen untuk menerbitkan buku ajar agar bisa menunjang bidang pendidikan yang lebih baik.

Dukungan industri dalam pengabdian kepada masyarakat dengan memberikan bantuan material maupun non material, agar pelaksanaan pengabdian kepada masyarakat bisa berjalan sesuai dengan rencana.

\section{METODE}

Berdasarkan hal tersebut diatas, dibutuhkan sebuah upaya pengabdian kepada masyarakat guna membekali keterampilan atau softskill yang dapat menunjang kemampuan individu, sehingga peserta mempunyai modal untuk berwirausaha dan bekerja serta bisa bersaing di dunia kerja. Untuk itu dengan memberikan pelatihan "Mengenalkan Wirausaha Dengan Keahlian Mengelas Bagi Karang Taruna dan Remaja Putus Sekolah Di Kecamatan
Cileungsi". Keterampilan yang dimiliki peserta nantinya dapat menambah kemampuan dan pengetahuan bagi peserta itu sendiri (Rose, Pate, Lawver, Warnick, \& Dai, 2015).

Pada jurnal ini menggunakan 2 data yaitu data primer dan data sekunder. Data primer berupa hasil pengamatan terhadap warga. Sedangkan data sekunder diperoleh melalui internet, literatur, dan lain-lain terhadap trending kebutuhan di bidang pengelasan. Untuk memperoleh data dari suatu observasi sangat diperlukan beberapa teknik pengumpulan data. Dalam memilih teknik tersebut maka perlu diperhatikan tingkat kesesuaiannya dengan realita sosial dari objek yang akan dilaksanakan pengabdian kepada masyarakat baik yang bersifat primer maupun sekunder.

a. Observasi (pengamatan langsung di lapangan), dilakukan dengan melakukan kuisioner terhadap pemahaman pengelasan.

b. Pengelompokan umur terhadap pemahaman pengelasan

c. Uji coba studi kasus dengan memberikan pelatihan pengelasan

d. Dokumentasi dan penggambaran untuk melihat kondisi lingkungan Kecamatan Cileungsi 


\section{HASIL \& PEMBAHASAN}

Kegiatan pelatihan pengelasan ini dilakukan di Sekolah Tinggi Teknologi Muhammadiyah Cileungsi dan dilakukan di salah satu Mitra masyarakat yaitu Karang Taruna Desa Dayeuh Kecamatan Cileungsi lihat gambar 24, agar peserta pelatihan mendapatkan ilmu yang bermanfaat dan bisa diaplikasikan di tempatnya masing-masing. Dari pihak STTMC memberikan materi dasar pengelasan, agar peserta pelatihan memahami dasar teknik pengelasan.

Ada beberapa peralatan pengelasan yang bisa dipergunakan, sesuai dengan gambar 2 \& 3 (Zaidi \& Madavi, 2018).

1. Las Listrik.

2. Las Asetilin.

3. Las TIG

4. Las MIG

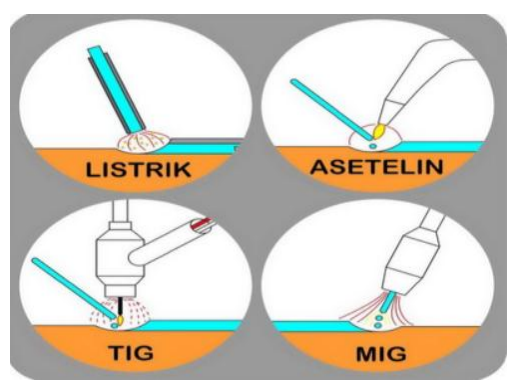

Gambar 2. Jenis-Jenis Las

\section{Kawat Las}

Kawat las atau elektroda las untuk mengisi sambungan atau kampuh las dengan cara membuat busur nyala pada kawat las pada gambar 4 .
2. Klasifikasi elektroda standar AWSASTM

Pada klasifikasi elektro harus disesuaikan dengan strandar nasional maupun internasional, adapun pada gambar 5, dijelaskan kode pada elektroda.

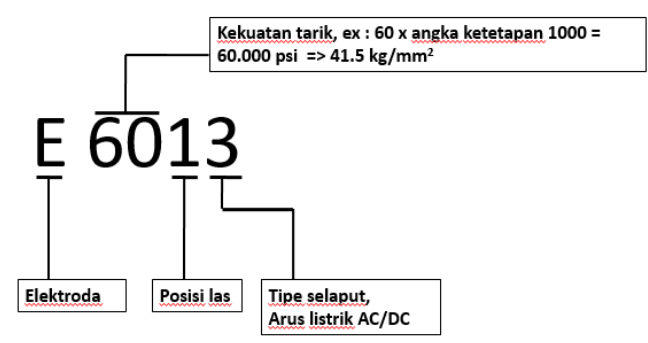

Gambar 3. Klasifikasi Elektroda

Gambar 4 kabel las untuk menyambungkan arus dari mesin las dibutuhkan 2 kabel power positif dan negatif. Kabel ini berfungsi mengalirkan arus ke elektroda.

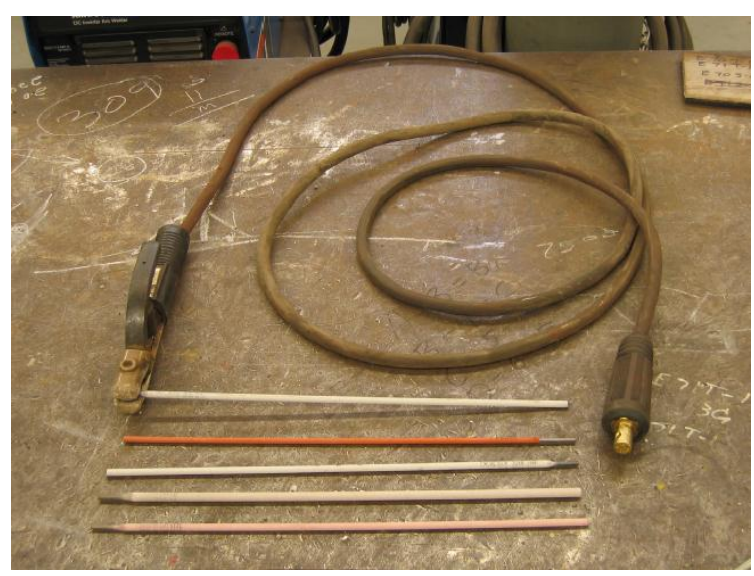

Gambar 4. Kabel Las (Los Alamos National Laboratory, 2015)

\section{Palu}

Palu ini berfungsi untuk membersihkan sisa pengelasan atau percikan logam dari pengelasan, dan memberikan tekanan pada logam yang dilas. 
4. Tang penjepit anti panas

Alat ini berfungsi untuk memindahkan benda kerja yang panas ke tempat pendinginan. Agar tidak membahayakan operator pengelasan.

5. Standar pengelasan.

Safe Working, dalam melakukan pengelasan, standar keselamatan harus diperhatikan agar tidak membahayakan pekerja (Codes, n.d.). Penggunaan perlengkapan keselamatan untuk pekerjaan pengelasan di kampung maupun di bengkel-bengkel yang sering kali tidak memenuhi standar keselamatan. Penggunaan perlengkapan keselamatan, pekerja yang melakukan pengelasan dengan menggunakan alat keselamatan apa adanya, akan membahayakan diri sendiri maupun orang lain (Los Alamos National Laboratory, 2015).

Perlengkapan keselamatan pada operator pengelasan, harus lengkap dipergunakan. Keselamatan pekerja lebih penting dibandingkan dengan produksi. Dengan menggunakan perlengkapan yang lengkap dapat meminimalisasi bahaya yang ditimbulkan serta menjaga kesehatan pekerja (Di \& Biologi, n.d.). Pada gambar 7, dijelaskan bagianbagian badan manusia yang harus menggunakan perlengkapan keselamatan.

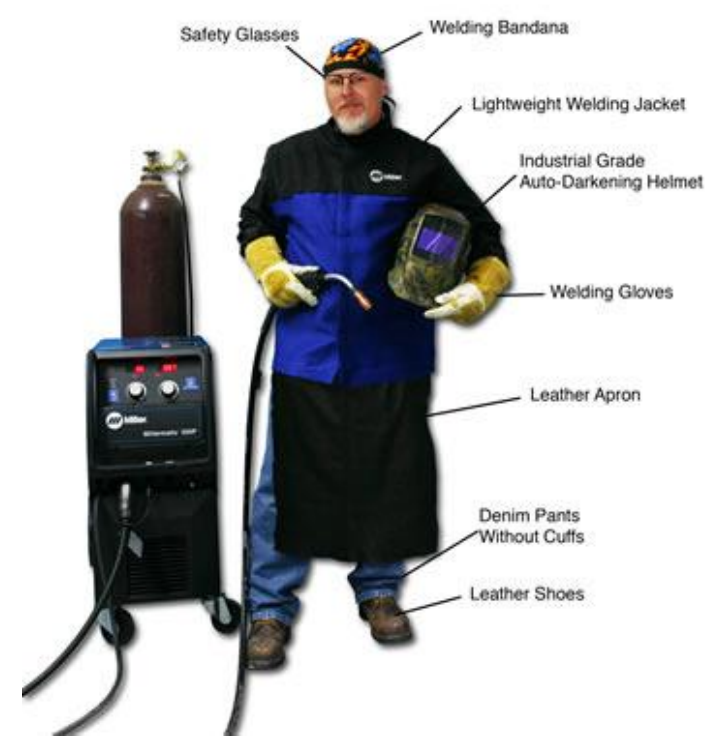

Gambar 7. Perlengkapan pengelasan yang aman (Welder, n.d.)

a. Peralatan Pengaman (Safety Equipment)

- Perlengkapan untuk keselamatan kerja, dari percikan api las maupun logam panas, untuk perlindungan muka atau mata, serta sinar ultraviolet harus menggunakan topi las yang aman (Mgonja, 2017).

- Agar saat mengelas tubuh terlindungi dari percikan api las, operator harus menggunakan apron.

b. Helmet Las

Didalam pelaksanaan pengelasan penggunaan helmet ini penting sekali, agar saat bekerja kepala tidak terbentur 
dengan benda kerja atau benda logam yang lain, serta menjaga keselamatan dalam bekerja (American \& Standard, 2012).

\section{c. Sepatu Las}

Pekerja bila tidak menggunakan sepatu safety akan membahayakan bagian kaki pekerja, dan jika menggunakan sepatu biasa akan membahayakan pekerja dalam melakukan pengelasan, karena percikan bunga api akan melukai kaki (Husaini, Setyaningrum, \& Saputra, 2016).

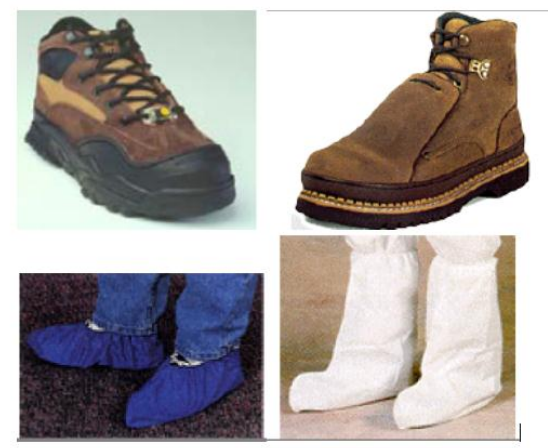

Gambar 8. Pelindung kaki (Handbook, 2007)

\section{d. Welding Glove}

Sarung tangan pada gambar 10 untuk pengelasan berfungsi untuk melindungi tangan terhadap paparan panas saat bekerja. jika tidak menggunakan sarung tangan akan membahayakan tangan kita (Mgonja, 2017).

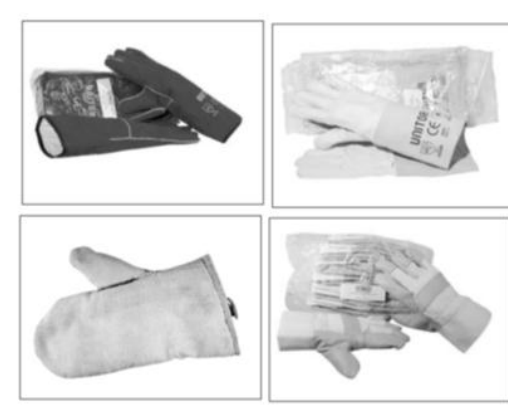

Gambar 9. Sarung tangan ("for maritime welders Maritime Welding Handbook," n.d.)

e. Baju Kerja las

Baju kerja untuk pengelasan berbeda dengan baju kerja biasa, dimana baju kerja las ini harus tahan api, tahan panas, agar saat dipergunakan tidak membahayakan pekerja, seluruh tubuh dilindungi oleh perlengkapan keselamatan yang dijelaskan pada gambar 10 (Alamanda Putri, 2019).

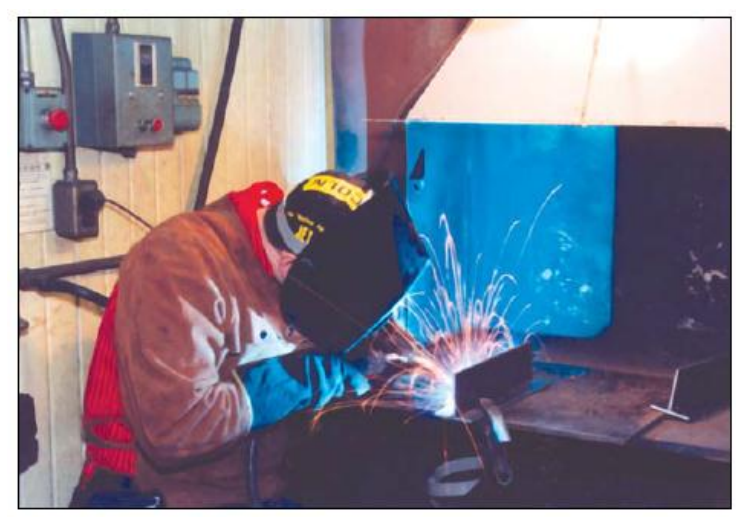

Gambar 10. Baju Kerja Las (Cooper, n.d.)

\section{f. Welding Room}

Pada saat mengelas, harus diperhitungkan terhadap tempat yang akan dipergunakan. Jika pengelasan dilakukan pada ruangan tertutup, harus diperhatikan sirkulasi udara diruangan tersebut. Asap dari hasil pengelasan akan membahayakan operator maupun 
orang lain, serta paparan asap jika terhirup oleh tubuh manusia, akan membahayakan keselamatan bagi pekerja (Harris \& Cih, 2020).

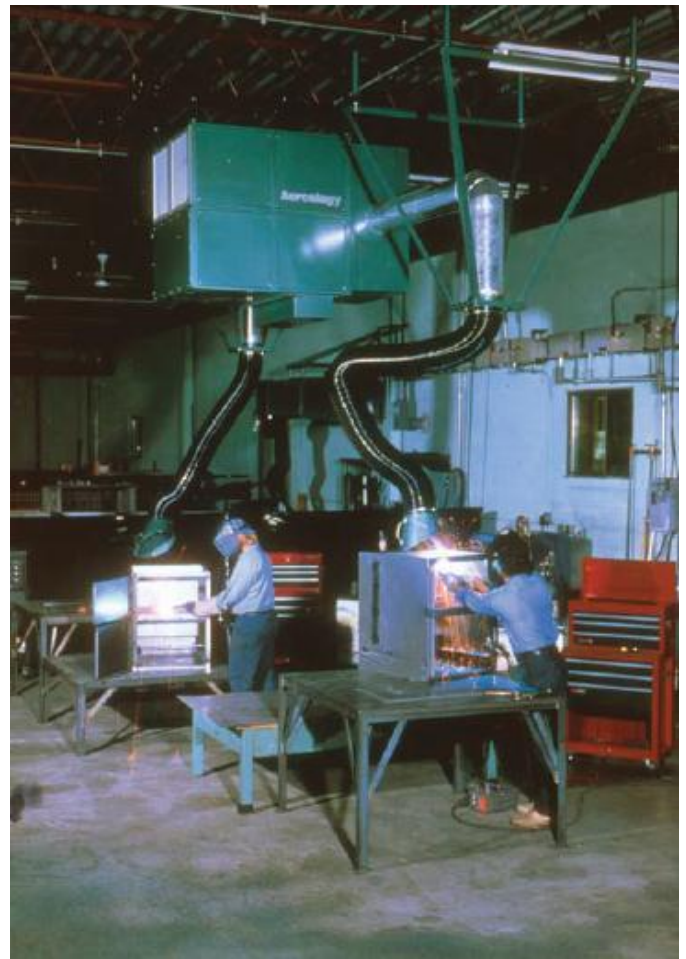

Gambar 11. Ruangan pengelasan (Cooper, n.d.)

g. Setting Arus.

Settingan arus pada tabel 1, peralatan las harus disesuaikan dengan mesin yang akan dipergunakan atau kapasitasnya. Terutama pada elektroda yang akan dipergunakan, jika dengan menggunakan elektroda 2,5 dialiri arus 150 190 A, hasil dari pengelasan tidak sempurna dan bisa menurunkan kualitas pengelasan (Praveen, John, \& Peethambaran, 2017).

Tabel 1. Setting arus pada peralatan pengelasan (Howard BC 1998)

\begin{tabular}{cc}
\hline $\begin{array}{c}\text { Diameter } \\
\text { Elektroda }\end{array}$ & Arus (ampere) \\
\hline 2.5 & $60-90$ \\
2.6 & $60-90$ \\
3.2 & $80-130$ \\
4.0 & $150-190$ \\
5.0 & $180-250$ \\
\hline
\end{tabular}

Gambar 12 ini menjelaskan cara setting arus pada peralatan las, cara setting harus dipahami dengan baik dan benar pada semua operator las, agar tidak salah melakukan setting peralatan kerja.

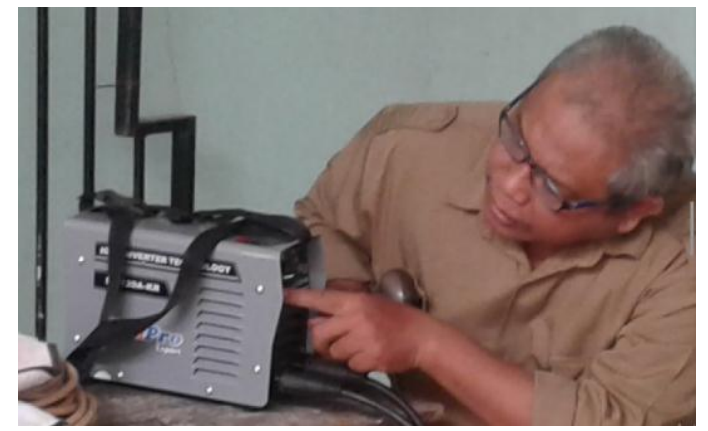

Gambar 12. Cara setting arus pada mesin las

h. Arah Gerakan Pengelasan.

Gerakan busur pengelasan ini, berbagai variasi dilakukan (GÜMÜŞa, ÇİÇEKa, İŞa, YILMAZa, \& TOPUZ, 2015), agar meningkatkan kualitas dan kekuatan pengelasan (Journal \& Mechanical, 2012).

Gerakan zig-zag (Mustafa \& Rao, 2016)

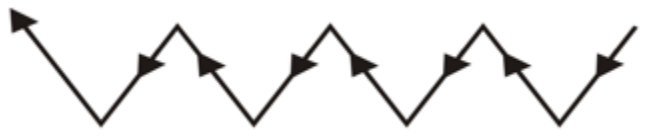

Gambar 13. Gerakan zig zag

- Gerakan melingkar 


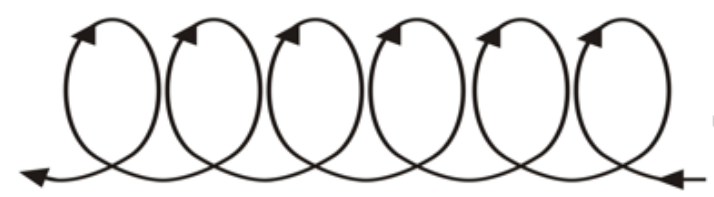

Gambar 14. Gerakan melingkar

- Gerakan segitiga

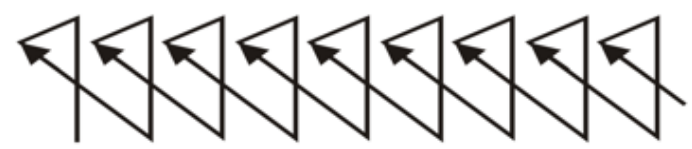

Gambar 15. Gerakan segitiga

i. Hasil Las

Kecepatan elektroda dalam melakukan pengelasan yang dijelaskan pada gambar 18, dimana berbagai kasus terjadi, jika operator las tidak memahami terhadap kecepatan pengelasan resikonya hasilnya tidak maksimal. (Hilmy \& Adestab, 2014)

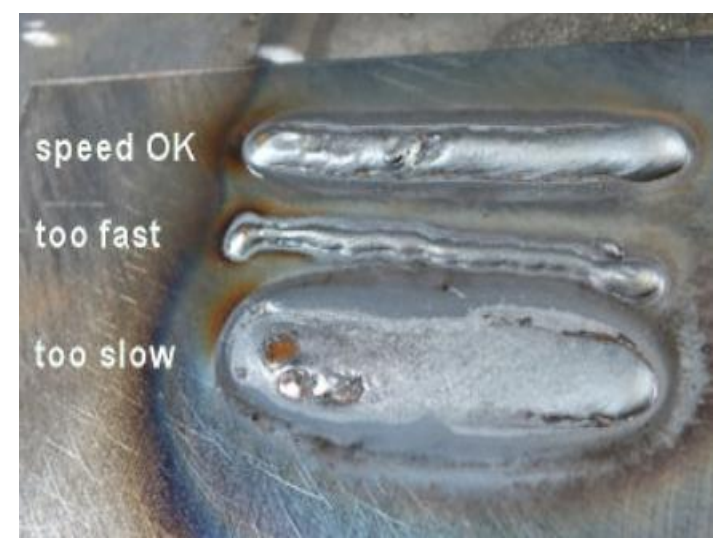

Gambar 16. Kecepatan elektroda

- Jarak elektroda ke benda kerja

(Hilmy \& Adestab, 2014)
p-ISSN 2721-1541 | e-ISSN 2721-5113

139

DOI: $10.30997 /$ ejpm.v1i2.2889

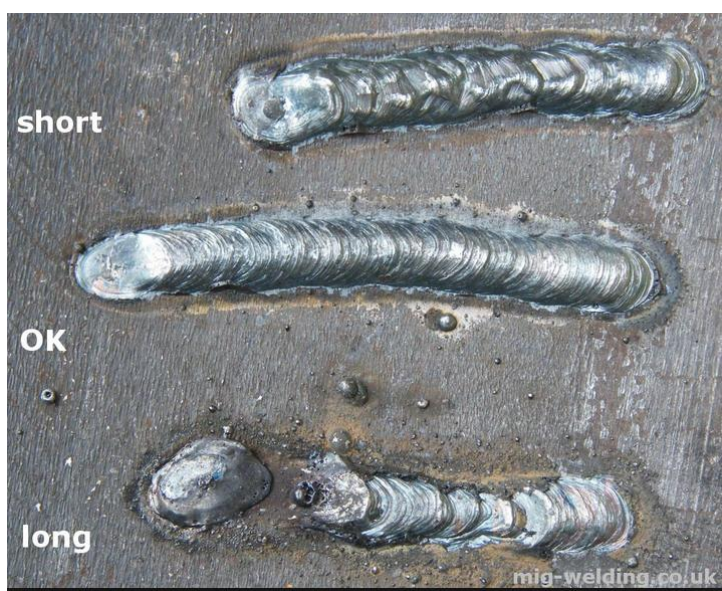

Gambar 17. Jarak elektroda

j. Cara melakukan pengelasan

Posisi dalam melaksanakan penge-

lasan berdampak besar terhadap kualitas pengelasan (Lei, Niu, Zhang, Fu, \& Feng, 2014).

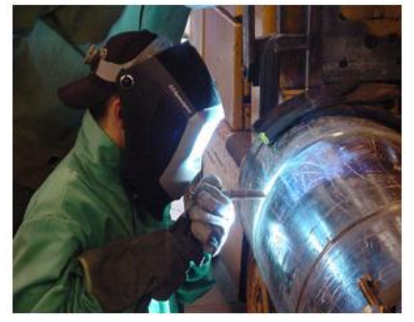

posisi $1 \mathrm{G}$

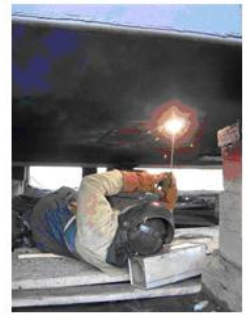

posisi 5G
Gambar 18. Posisi pengelasan 1 G dan 5 G

k. Praktek Pengelasan

Sebelum peserta mengikuti praktek pengelasan, terlebih dahulu peserta diberikan materi teori agar memahami cara kerja alat las dan resiko kerja pada saat menggunakan alat las listrik.

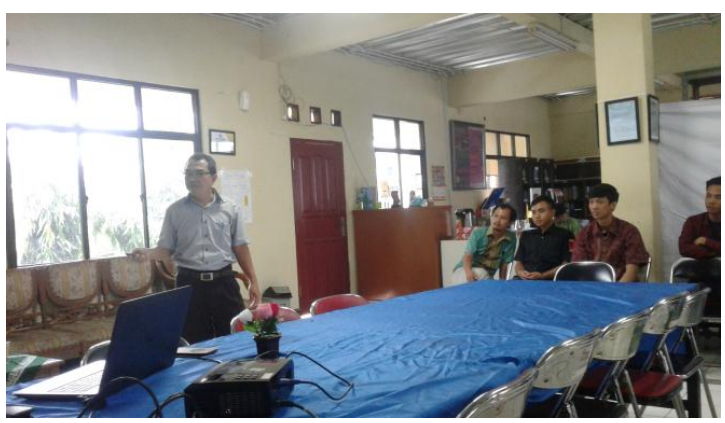


Gambar 19. Menyampaikan materi

Pada gambar 20 semua peserta pengelasan foto bersama sebelum melakukan pelatihan pengelasan.

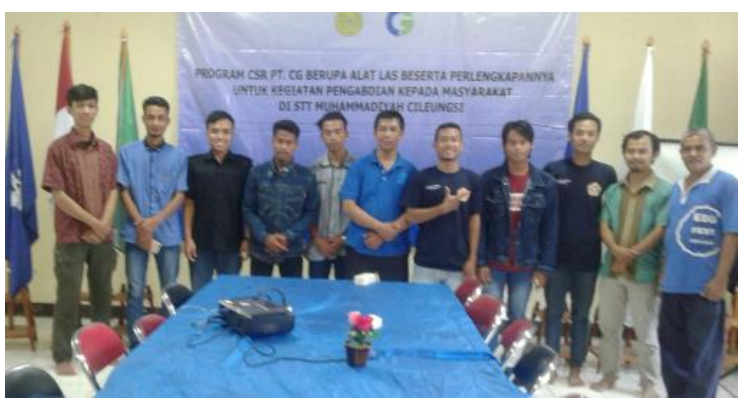

Gambar 20. Peserta pelatihan

Instruktur memberikan contoh cara penggunaan peralatan keselamatan sebelum mengoperasikan mesin las, peragaan ini agar peserta memahami betul perlengkapan keselamatan yang harus dipergunakan. Penggunaan sarung tangan maupun pelindung tangan untuk melindungi tangan dari percikan bunga api pada saat melakukan pengelasan.

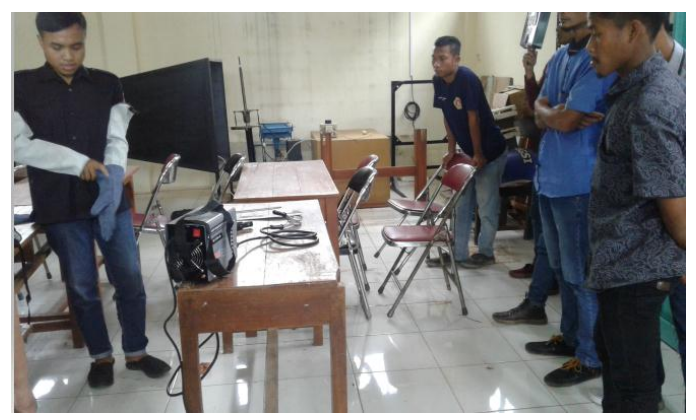

Gambar 21. Cara menggunakan perlengkapan keselamatan

Bagaimana mengoperasikan alat las listrik ini, sebelum mengoperasikan peserta harus memahami fungsi masing-masing peralatan mesin las, agar tidak salah mempergunakan peralatan las. Setiap peralatan las mempunyai fungsi yang berbeda-beda, jika salah koneksi maupun setting alat las akan mengakibatkan kecelakaan pada pekerja maupun kerusakan pada peralatan kerja yang dijelaskan pada gambar 24.

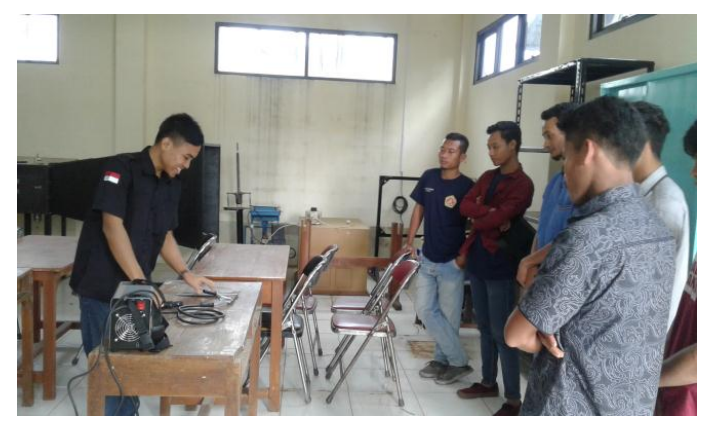

Gambar 22. Penjelasan perlengkapan las.

Gambar 23 proses penyambungan terhadap 2 benda dengan menggunakan mesin las.

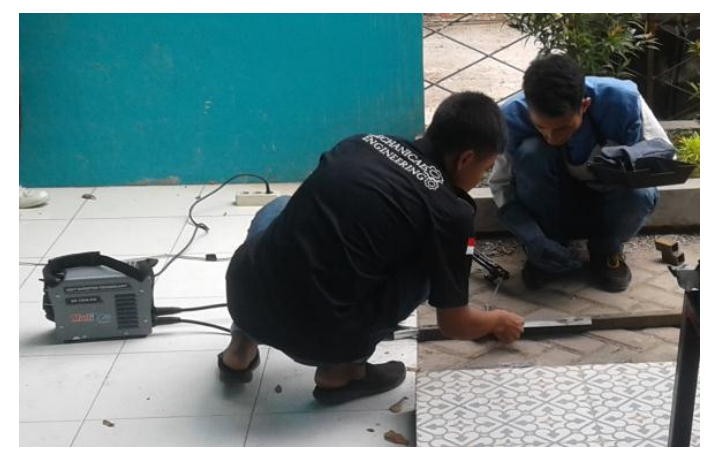

Gambar 23. Instruktur memberikan pengarahan pada saat pengelasan

\section{SIMPULAN}

Kegiatan pengabdian kepada masyarakat pelatihan pengelasan terlaksana dengan baik dan diikuti beberapa perwakilan dari setiap karang taruna yang diundang. Dalam pelatihan peng- 
elasan ini melibatkan CSR perusahaan dari PT. CG Power Systems Indonesia untuk pengadaan peralatan las dan perlengkapannya. Dibutuhkan waktu yang lebih lama dalam memberikan pelatihan pengelasan, agar peserta pelatihan mendapatkan hasil yang maksimal.

\section{UCAPAN TERIMA KASIH}

Kepada jajaran manajemen PT. CG Power Systems Indonesia yang telah memberikan sumbangan berupa peralatan las, dan memberikan support terhadap pelaksanaan Pengabdian kepada Masyarakat yang telah dilaksanakan. Kami ucapkan terima kasih kepada Ketua STTMC yang telah memberikan arahan terhadap pelatihan pengelasan yang dilaksanakan oleh LPPM dan Dosen STTM.

\section{DAFTAR PUSTAKA}

Alamanda Putri, N. A. (2019). the Analysis of Personal Factors Causing Substandard Act in Using Self Protective Equipment for Welding. The Indonesian Journal of Occupational Safety and Health, 8(1), 11.

https://doi.org/10.20473/ijosh.v8i 1.2019.11-19

American, A., \& Standard, N. (2012). Safety in Welding, Cutting, and Allied Processes ${ }^{\circledR}$ ANSI Z49.1:2012 An American National Standard Safety in Welding, Cutting, and Allied Processes.
Architecture, N., Operations, M. E., \& Operations, M. E. (2011). Welding Technologies in Shipbuilding Industry. Tojsat, 1(4), 24-30.

Codes, I. L. O. (n.d.). Safety and health in the construction of fixed offshore installations in the petroleum industry.

Cooper, M. (n.d.). SAFE.

Di, M., \& Biologi, L. (n.d.). EVALUASI PENERAPAN PRINSIP

KESEHATAN DAN KESELAMATAN KERJA ( K3 )

PADA PELAKSANAAN KEGIATAN PRAKTIKUM.

European, C. (2013). Guidance on the protection of the health and safety of workers from the potential risks related to nanomaterials at work Guidance for employers and health and safety practitioners, 63 .

Golbabaei, F., \& Khadem, M. (2015). Air Pollution in Welding Processes Assessment and Control Methods. Current Air Quality Issues, (October). https:// doi.org/10.5772/59793 GÜMÜŞa, E., ÇİÇEKa, B., İŞa, E. G., YILMAZa, E., \& TOPUZ, P. (2015). Risks and Safety Measures in Tig. ResearchGate, (March 2017).

Handbook, B. N. L. (2007). BNL Handbook on Personal Protective Equipment ( PPE ) Selection and Use, 1.

Harris, M., \& Cih, P. D. (2020). Welding Safety: Welding APPLICATIONS Fumes, 1-23.

Hilmy, I., \& Adestab, E. Y. T. (2014). Welding performance of a homemade friction stir welding tool. Applied Mechanics and Materials, 446-447, 660-664. https:/ / doi.org/10.4028/www.sci entific.net/AMM.446-447.660

Husaini, Setyaningrum, R., \& Saputra, 
M. (2016). Analysis of affecting factors of work accidents and use of personal protective equipment in welders in A. Yani Street Banjarbaru 2016. International Journal of Applied Business and Economic Research, 14(5), 2845-2855.

Id, M., Type, M., \& Education, M. (2008). Anzam 2008.

Journal, I., \& Mechanical, O. F. (2012). Ijmet ( $\mathrm{I}$ a E M E Optimization of Process Parameters for 316L, 3(2), 67-72.

Lankoti, M. D., \& Tech, B. (2019). Optimistic Ethical Culture in Work Place for Sustainable Human Development, VIII(Xii), 107-109.

Lei, X., Niu, J., Zhang, J., Fu, A., \& Feng, Y. (2014). Failure Analysis of Weld Cracking in a Thick-Walled 2 . 25Cr-1Mo Steel Pressure Vessel, (March 2015). https://doi.org/10.1007/s11665014-0893-z

Los Alamos National Laboratory. (2015). Study Guide Electrical Safety Hazards Awareness This Guide Should Be Used By Instructors To Supplement the Non-Electrical, 1-49.

Mgonja, C. T. (2017). The effects of arc welding hazards to welders and people surrounding the welding area. International Journal of Mechanical Engineering and Technology, 8(3), 433-441.

Michie, J., \& Sheehan, M. (2005). Business strategy, human resources, labour market flexibility and competitive advantage. International Journal of Human Resource Management, 16(3), 445464.

https://doi.org/10.1080/09585190 42000339598

Mustafa, F. F., \& Rao, M. I. (2016).
Automatic Welding Machine For Pipeline Using MIG Welding Process. International Research of Engineering and Technology (IRJET), 3(12 Desember), 1-7.

Praveen, V. V., John, T. D., \& Peethambaran, K. M. (2017). Experimental investigation of welding parameters on automatic TIG welding of aluminium 5083 plate. Materials Science Forum, 879(2), 1459-1464.

https://doi.org/10.4028/www.sci entific.net/MSF.879.1459

Rose, M., Pate, M. L., Lawver, R. G., Warnick, B. K., \& Dai, X. (2015). Assessing the Impact of Sequencing Practicums for Welding in Agricultural Mechanics. Journal of Agricultural Education, 56(1), 92-102. https://doi.org/10.5032/jae.2015.0 1092

Vishnu, L., \& Tunuguntla, M. (2017). Relationship between building human resources and business value planning, 7(6), 334-348.

Weber, M. R., Crawford, A., \& Dennison, D. (2012). North Carolina Human Resource Professionals' Perceptions of Soft Skill Competencies. Journal of Human Resources in Hospitality and Tourism, 11(3), 225-238. https:// doi.org/10.1080/15332845. 2012.668655

Welder, T. W. (n.d.). The Basics of Welding Safety.

Windusari, K., \& Magelang, K. (n.d.). Pelatihan Pengelasan Karang Taruna Desa Balesari , 37-44. Zaidi, A., \& Madavi, P. K. R. (2018). Improvement of Welding Penetration in MIG Welding, 4(5), 1198-1203. 